\title{
NOTES
}

\section{WORKMEN'S COMPENSATION LAWS AND EQUAL PROTECTION: DOES GALLEGOS PORTEND THE DEMISE OF THE AGRICULTURAL EXCLUSION?}

Despite the fact that about eight-five percent of employed wage and salary workers in the fifty states and the District of Columbia are presently covered by workmen's compensation, ${ }^{1}$ only nine states provide total workmen's compensation coverage for the agricultural einployee. ${ }^{2}$ More importantly, perhaps, only three of the twelve leading farm states extend total coverage to the farm worker, and statutes in seven of these states provide no coverage whatsoever for the agricultural employee. ${ }^{3}$ Because of the agricultural exclusion and the additional fact that the compensation laws of nineteen states are elective, giving the employer the option of accepting or rejecting the provisions of the act, ${ }^{4}$ the bulk of American farm workers have found themselves

1. Report of the National Commission on State Workmen's Compensation LAws 43 (1972).

HEREINAFTER THE FOLLOWING CITATIONS WILI BE USED IN THIS NOTE:

A. LARSON, The LaW of Workmen's COMpensation (1970) [hereinafter cited as LARSON];

Report of the National COMmission on STate Workmen's COMPENSation Laws (1972) [hereinafter cited as CoMmISSION REPORT];

U.S. Bureau of the Census, Dep'T of Labor, Statistical Abstract of the United States (92d ed. 1971) [hereinafter cited as Statistical Abstract].

2. For an explanation of the concept of "total" workmen's compensation coverage and a list of the states which provide it, see note 28 infra and accompanying text.

3. Based on value of farm products sold, the twelve leading agricultural states are, in descending order: California, Iowa, Texas, Illinois, Minnesota, Nebraska, Kansas, Indiana, Wisconsin, North Carolina, Missouri, and Ohio. Statistical Abstract 575. Of these states, California, Wisconsin, and Ohio provide total benefits to the agricultural laborer, see note 28 infra, while Iowa, Texas, Nebraska, Kansas, Indiana, North Carolina, and Missouri exclude agricultural employees from the compensation systein entirely. For an explanation of the concept of "no coverage" under workmen's compensation, and a list of states which deny compensation coverage to farm workers, see note 34 infra and accompanying text.

4. The following states have elective workmen's compensation systems: Alabama, Ala. Code tit. 26, \$ 273 (1958); Colorado, Colo. Rev. STAT. ANN. \$ 81-4-1 (1963); Florida, Fla. Stat. ANN. \$440.05 (1966); Indiana, Ind. ANN. Stat. \$ 40-2202 (1965); Kansas, Kan. Stat. ANN. \$§ 44-542, -543 (1964); Louisiana, LA. Rev. Stat. § 23:1038 (1964); Maine, Me. Rev. Stat. ANN. tit. 39, § 21 (1964); Missouri, Mo. Rev. Stat. § 287.060 (1969); New Jersey, N.J. Rev. Stat. \& 34:15-9 (1937); 
without the relatively quick and simple means of redress provided by workmen's compensation.

The consequences to agricultural workers of exclusion ${ }^{5}$ from the coverage of a workmen's compensation statute are quite severe. The accidental death rate for agricultural employment ranks behind only mining and construction as the highest among all work groups, ${ }^{\circ}$ and the incidence of disabling imjury among farm workers is also extraordinarily high. Those injured agricultural workers who are excluded from compensation coverage, or their surviving dependents, are forced to fall back on tort actions for recovery, a remedy which the National Commission on State Workmen's Compensation Laws has termed "a drawn-out, costly, and uncertam process that was dismissed long-ago as a means of dealing with occupational injuries and diseases." The advantages of the workmen's compensation systemprompt payment with minimum legal formality in which the cost of work imjuries is considered part of the cost of production-are unavailable to the vast number of these claimants. ${ }^{8}$ While social security dis-

New Mexico, N.M. Stat. ANN. § 59-10-4 (1953); North Carolina, N.C. Gen. Stat. $\S 97-3$ (1972); Pennsylvania, Pa. Stat. AnN. tit. 77, § 461 (1952); Rhode Island, R.I. Gen. LAws ANN. § 28-29-8 (1952); South Carolina, S.C. CODE ANN. § 72-101 (1962); South Dakota, S.D. Comp. LAws AnN. $\$ 62-3-3$ (1967); Tennessee, Tenn. Code AnN. $\$ 50-903$ (1966); Texas, Tex. Rev. Crv. Stat. AnN. art. 8309 (1967); Vermont, VT. Stat. ANN. tit. 21, \& 612 (1967); West Virginia, W. VA. Code ANN. $\S 23-2-6$ (1966). See 2 Larson \& 67.10 (1970).

The elective approach has been a part of the workmen's compensation system from the beginning, as it was originally thought to be constitutionally mandated. While this reasoning has been discarded, the elective concept has nonetheless survived. CoMMISSION REPORT 44-45. If an employer elects not to be covered by the act, he loses his customary common law defenses-assumption of the risk, the fellow servant rule, and contributory negligence. U.S. BUREAU OF LABOR STANDARDS, DEP'T OF LABOR Bull. No. 206, Agricultural Workers AND WorkMEN's Compensation 5 (1969 revision).

5. Professor Larson divides statutory exemptions of particular categories of employces into two groups, the major and the minor. Within the major exemptions which appear in the majority of statutes are exemptions of: domestic, agricultural, and casual employees; those employed not in the course of the employer's trade, business, or profession; and employees falling within the numerical minimum excmption. Under the numerical minimum exemption, those ejnployers having less than a specified minimum number of employees are not required to provide workmen's compensation coverage. The numerical minimums range from less than two employees to less than fifteen employees. 1A LARSON $\$ 52.10$. The minor exemption category includes: workers in nonhazardous, public, nonprofit, religious, or charitable employment, newsboys, and corporate executives. $I d$. $\$ 50.10$.

6. National Safety Council, Accident Facts 23 (1968). See text accompanying note 24 infra.

7. COMMISSION REPORT at 45.

8. U.S. Bureau of Labor Standards, Dep't of Labor, Buld. No. 161, State WORKMEN'S COMPENSATION LAWS 1 (1969 revision). 
ability benefits ${ }^{9}$ may afford some relief, many agricultural workers do not possess the financial means necessary to pursue a legal remedy to redress their work-related injuries. ${ }^{10}$

Because of the prevalent agricultural exclusion, a vast amount of legal energy in the workmen's compensation area has been expended in delineating who is and who is not an "agricultural employee" within the meaning of the compensation statutes. ${ }^{11}$ Predominant areas of dispute include activities in the cominercial production and processing of agricultural cominodities, ${ }^{12}$ and controversies involving employees who work part time in agriculture and part time in non-agricultural pursuits. ${ }^{13}$

This Note will review the justifications for the agricultural exclusion in the workmen's compensation scheme. Following a discussion of the various statutory approaches involving workmen's compensation coverage for the farm worker, judicial rationales attacking the constitutionality of the agricultural exclusion will be examined. Emphasis will be placed on the recent decision by the Supreme Court of Michigan in Gallegos v. Glaser Crandell Co., ${ }^{14}$ the first case to hold that an agricultural exclusion in a workmen's compensation statute is an arbitrary

9. See 42 U.S.C. $\$ 401$ et seq. (1970); notes $99-100$ infra and accompanying text.

10. The National Commission on State Workmen's Compensation Laws recognized that the farm worker is unlikely to have personal insurance or savings. Commission REPORT 46. In 1969, the median earnings per day of the farm wage worker was $\$ 8.50$. Statistical AbSTRACT 232. For recent articles dealing with the plight of agricultural workers, including the migrant worker in particular, see, e.g., Givims, Legal Disadvantages of Migratory Workers, 16 LAB. L.J. 584 (1965); Note, The Farm Worker: His Need for Legislation, 22 MAINE L. REv. 213 (1970); Note, Florida's Forgotien People: The Migrant Farmworkers, 23 U. FLA. L. Rev. 756 (1971).

11. See 1A LARson $\S \S 53.30-40$. See also Annot., 140 A.L.R. 399 (1942); Annot,, 107 A.L.R. 977 (1937); Annot., 43 A.L.R. 954 (1926); Annot., 35 A.L.R. 208 (1925); Annot., 13 A.L.R. 955 (1921); Annot., 7 A.I.R. 1296 (1920).

12. See, e.g., Pestlin v. Haxton Canning Co., 299 N.Y. 477, 87 N.E.2d 522 (1949), where claimant was injured while operating a tractor-powered beet topping machine. The cannery owned the farm, tractor, and machine, and the beets liad been sold in advance to the cannery. While the majority held the employee's activity to fall within the farm labor exemption, the minority felt that the removal of beet tops was the first stage in the canning process, and that accordingly the agricultural exemption slrould not apply.

13. See, e.g., Guerroro v, United States Fidelity \& Guar. Co., 128 Tex. 407, 98 S.W.2d 796 (1936), where a florist occasionally raised plants himself, but also purchased shrubs which he temporarily placed in the ground for preservation. The court held that a person who grows plants for sale is engaged in an agricultural pursuit, while one who is involved in the business of buying and selling nursery stock which is put in the ground temporarily for preservation is not engaged in agriculture within the meaning of the act.

14. 388 Mich. 654, 202 N.W.2d 786 (1972). 
and unreasonable classification in violation of the equal protection clauses of the United States and Michigan constitutions. Implications of the Gallegos rationale in expanding the reacli of various types of social legislation to the farm worker will also be considered.

\section{LEGISLATTVE APPROACHES TO WORKMEN'S COMPENSATION COVERAGE OF AGRICULTURAL EMPLOYEES}

\section{Justifications for the Agricultural Exclusion}

A common explanation for the exclusion of agricultural workers froin workmen's coinpensation statutes is that the exeinption was politically expedient as a legislative compromise to secure the rural support needed to enact the first workmen's compensation statutes. ${ }^{15}$ This political factor may explain why the exclusion still remains in the majority of the leading agricultural states. ${ }^{16}$ Apart from this explanation, an investigation of the justifications for the agricultural exclusion reveals that many such arguments are obsolete, and all appear to be untenable.

The most frequently voiced justification for the agricultural exclusion in workmen's compensation schemes is the administrative impracticability of including agricultural workers within the coverage of the statute. ${ }^{17}$ When workmen's compensation laws were passed in the early decades of the twentieth century, it was thought that the farm employer would be unreasonably overburdened in handling the necessary records, insurance, and accounting. Granting the wisdom of this reasoning at that early date, the current trend towards large-scale farming with crop specialization and mechanization ${ }^{18}$ makes such reasoning unacceptable today. Even the small farmer must now accept the bookkeeping burdens of income tax, FICA assessments, and unemployment insurance. ${ }^{19}$ Consequently, adding compensation insurance accounting to his list would not place an onerous burden on the farm einployer.

15. See Davis, Death of a Hired Man-Agricultural Employees and Workmen's Compensation in the North Central States, 13 S.D.L. Rev. 1, 4 (1968). New York passed the first workmen's compensation act in 1910. By 1920, all but eight states had adopted acts. In 1949, Mississippi became the last state to come under the system. 1 LARSON $\$ \S 5.20,5.30$.

16. See note 3 supra and accompanying text.

17. See 1A LaRSON $\$ 53.20$.

18. The value of farm machinery and equipment has risen ifrom a total of $\$ 12,166,000,000$ in 1950 to a total of $\$ 34,299,000,000$ in 1970. Statistical Abstract 579.

19. See Note, Workmen's Compensation-Washington's Recent Amendments: Universal Mandatory Coverage, Liberalized Benefits, and a Controversial Two-Way Plan, 47 WASH. L. REv. 717, 722 (1972). 
A second justification for excluding the farm worker from workmen's compensation coverage is that the farmer, unlike the manufacturer, cannot add his compensation cost to the price of his product and pass it on to the consumer. ${ }^{20}$ Because of intense competition and frequent inability to control the selling price of his product, the farmer's power over his market is often weaker than that of the average manufacturer or retailer. However, as Professor Larson recognizes, should farm labor be covered in all states, there would be no competitive advantage as far as the domestic market is concerned, and the domestic-world inarket disparity should not differ because of this sliglit increase in doinestic farm cost. ${ }^{21}$

The legislative histories of various compensation statutes reveal a third justification for the failure of legislatures to extend workmen's compensation coverage to farm workers-the philosophy that farming was not thought to be a hazardous employment deserving of coverage. $^{22}$ Recent safety studies which indicate a sharp increase im the use of ineclranized equipinent on farms and a concomitant high incidence of deatli and disabling injury to farm workers point out the fallacy behind such an assumption. ${ }^{23}$ In fact, the 2,700 deaths and 230,000 disabling mjuries sustained by farm employees in 1967 reflect the very real hazards involved in agricultural enployment. ${ }^{24}$

A final justification for the exclusion of agricultural employees is largely historical. Because of the large number of "family farms" in operation in the early twentieth century, many legislators feared that such farms might be compelled to provide compensation coverage for family menbers. ${ }^{25}$ However, it appears that this fear could easily be

20. See 1A LARson § 53.20. See also Davis, supra note 15, at 6-9.

21. 1A LARSON $\$ 53.20$.

22. See Note, supra note 19 , at 722 .

23. The dramatic increase in the use of mechanized farm equipment, see note 18 supra, brings with it the attendant risks of personal injuries caused by equipment misuse or malfunction. Another and perhaps even more frightening aspect of the hazards of farn employment is the risk of pesticide poisoning. Powerful pesticides, often purchased illegally, may be applied in the wrong place or in the wrong amount. Frequently, no advance preparations are made for emergency care in case of an accident. The farm worker may be given no instructions concerning the hazards surrounding the use of the poison, precautions about its use, or protective clothing to be worn during application of the poison. See Hanner, Poisons, Profits and Politics: Cases of Death and Severe Illness Due to Pesticide Poisoning in California, 209 Natron 134 (1969). Furthermore, poisons resembling military nerve gas are often used in the agricultural fields, and there have beeu numerous cases of farm workers, as well as their children, suffering serious adverse effects from pesticide poisoning. See Taylor, Nerve Gas in the Orchards: Pesticide Poisoning, 210 Nation 751 (1970).

24. National Safety Council, Accident Facts 23 (1968).

25. See Davis, supra note 15 , at 5 . 
eradicated by excepting family members from the coverage of the act. ${ }^{20}$ In addition, the intensity of such fears should have diminished over the years due to the sharp decline in the number of farms operating in the United States. ${ }^{27}$

\section{Statutory Schemes: Varying Compensation Coverage for Agricultural Employees}

The legislative response to the plight of the agricultural worker has been, at best, sporadic. Three different approaches to workmen's coinpensation coverage are discernible. Nine states and Puerto Rico provide total coverage for agricultural employees, granting them all the benefits extended to other employees under the workmen's compensation statute. ${ }^{28}$ It should be noted, however, that some of these states, although purporting to provide total coverage, impose numerical minimums which, as a practical matter, exclude all small farms from the coverage of workmen's compensation. ${ }^{20}$ Fifteen states provide partial workmen's compensation coverage for the farm worker, extending compensation benefits to such employees but imposing substantial limitations on their availability. ${ }^{30}$ Coverage may differ widely, sometimes

26. See, e.g., IrL. ANN. Stat. ch. $48, \S 138.3$ (Smith-Hurd Supp. 1972), amending IrL. ANN. STAT. ch. 48, $\$ 138.3$ (Smith-Hurd 1969). It should be noted, however, that it was precisely this type of irrational categorization that prompted the Michigan Supreme Court to strike down the agricultural exclusion in Gallegos. See notes 67-69 infra and accompanying text.

27. The number of farms in the United States has dropped from a total of $6,518,000$ in 1920 to $2,876,000$ in 1971 , while the average number of acres per farm has increased from 147 in 1920 to 389 in 1971. Statistical Abstract 573.

28. The following jurisdictions provide total coverage for the farm worker: California, CaL. LABor Code \& 3351 (West 1971); Comecticut, ConN. GEN. STat. ANN. $\S 31-275$ (1972); Hawaii, HAWAI Rev. LAws $\S 396-1$ (1968); Massachusetts, MAss. Gen. Laws ch. 152, § 1 (1965); New Jersey, N.J. Rev. StaT. \$§ 34:15-36 (1959), 34:15-92 (Supp. 1972); Ohio, OHo Rev. Code ANN. $\$ 4123.01$ (Page 1965); Oregon, ORE. REv. Stat. \& 656.027 (1971); Puerto Rico, P.R. LAws ANN. tit. 11, \& 2 (1962); Vermont, VT. STat. ANN. tit. 21, \& 601 (1967); Wisconsin, Wis. STat. ANN. \& 102,07 (1957).

29. See, e.g., VT. STaT. ANN. tit. 21, § 616 (Supp. 1970), where, while making no specific exemption for agriculture, a numerical mimium of three or more employees is imposed.

30. The designation "partial coverage" encompasses a variety of situations in which only certain farm workers are accorded full benefits under the act, or in which certain time or numerical limitations determine the status of coverage under the act. The following jurisdictions provide partial coverage for the farm worker: Alaska, ALASKA STAT. \$ 23.30.230 (1962) (harvest help and similar part-time or transient help not covered); Arizona, ARtz. Rev. Stat. ANN. \& 23-902 (1971) (exempts agricultural workers not employed in the use of machinery); Florida, FLA. STAT. ANN. $\$ 440.02$ (Supp. 1973) (excludes agricultural labor employed by a farmer or agricultural association with nine or fewer regular employees and which employs fewer than twenty 
extending only to those workers using machinery or power equipment, ${ }^{31}$ sometimes covering all farm employees except those with a minimum amount of earnings ${ }^{32}$ or those working only on a seasonal basis. ${ }^{33}$ Finally, twenty-five states and the District of Columbia provide no coverage whatsoever for the farm worker. ${ }^{34}$

other employees at any one time for seasonal agricultural labor completed in less than thirty days, provided such seasonal employment does not exceed sixty days in the same calendar year); Illinois, ILL. ANN. STat. ch. 48, § 138.3 (Smith-Hurd Supp. 1972) (excludes employees of farmer employing less than 500 man-days of labor per calendar quarter and all exchange and family labor); Kentucky, KY. REv. STAT. ANN. § 342.005 (Supp. 1972) (covers workers engaged in operation of threshing or hulling machines); Louisiana, LA. REV. StaT. § 23:1035 (1964) (covers workers engaged in operation of harvesting and threshing machinery); Maine, ME. REv. StaT. ANN. tit. 39, § 4 (Supp. 1972-73) (excludes seasonal or casual workers); Maryland, MD. ANN. CODE art. 101, $\S 21$ (Supp. 1972) (excludes employers of less than three full-time employees, einployers with an annual payroll of less than $\$ 15,000$ for full-time employees, and excludes all seasonal or migratory employees who do not operate machinery or equipment); Michigan, Mich. CoMp. Laws $\S 418.115$ (Supp. 1972) (covers farm workers who work for 35 hours or more a week for a period of 13 weeks or more per year for an employer who employs three such regular employees or more; provides only medical and hospital coverage for employees working 35 hours or more a week for five or more weeks for an employer who employs at least one such employee); Minnesota, Minn. STaT. ANN. $\S 176.011,176.041$ (1966) (covers only workers engaged as commercial threshermen or balers); New Hampshire, N.H. REv. STAT. ANN. $\S 281: 2$ (Supp. 1972) (covers farm workers working for an employer who employs more than two employees); New York, N.Y. WorkMEN's CoMP. Law, $\$ 3$, group 14-b (McKinney Supp. 1972-73) (requires coverage of farm workers for 12 months from April 1 of a given year, if the employer's cash wage payments during the preceding calendar year exceeded $\$ 1,200$ ); South Dakota, S.D. CoMp. LAws ANN. \$§ 62-3-15, 62-3-16 (1967) (covers only workers engaged in operation of harvesting machines); Washington, WASH. REV. CODE $\$ 51.12 .020$ (Supp. 1972) (excludes seasonal workers and employees earning less than $\$ 150$ a calendar year from any one employer); Wyoming, WYo. STat. ANN. \$§ 27-49, 27-61 (Supp. 1971) (covers only workers engaged in power farming for an average of six months per year).

31. See, e.g., ArIz. Rev. Stat. AnN. \& 23-902 (1971).

32. See, e.g., WASH. REv. CODE $\$ 51.12 .020$ (Supp. 1972).

33. See, e.g., Alaska Stat. $\$ 23.30-230$ (1962).

34. The designation "no coverage" may apply to statutes in which farm workers are omitted from a list of covered employments or in which farm workers are definitively excluded from the act. The following jurisdictions provide no coverage for the farm worker: Alabama, AIA. CODE tit. 26, § 263 (Supp. 1971); Colorado, Colo. REv. StaT. ANN. § 81-2-6 (1964); Delaware, DEL. CODE ANN. tit. 19, § 2307 (1970); District of Columbia, D.C. CODE ANN. $\$ 36-502$ (Supp. 1970); Georgia, GA. CODE ANN. \$ 114-107 (1956); Idaho, IDAHo Code § 72-105 (1947); Indiana, IND. ANN. STAT. \$ 40-1209 (1965); Iowa, Iowa CODE ANN. § 85.1 (Supp. 1973); Kansas, KaN. Stat. ANN. \$ 44-505 (1964); Mississippi, Miss. Code ANN. § 6998-03 (Supp. 1972); Missouri, Mo. Rev. Stat. \$ 287.090 (Supp. 1973); Montana, Mont. Rev. Codes ANN. § 92-202 (1964); Nebraska, Neb. Rev. Stat. § 48-106 (1968); Nevada, Nev. Rev. STAT. § 616.060 (1967); New Mexico, N.M. STaT. ANN. \$§ 59-10-2, 59-10-10 (1960); North Carolina, N.C. GeN. Stat. \$ 97-13 (1972); North Dakota, N.D. Cent. Code \$ 65-01-02 (Supp. 1971); Oklaholna, OKLA. STAT. ANN. tit. 85, \& 2 (1970); Pennsyl- 
Several recent legislative developments, however, indicate that the relatively large number of states denying any workmen's compensation coverage whatsoever to farm workers may decrease in the future. For example, in 1971 Maryland amended its act, repealing a prior exemption of any person employed in agriculture. ${ }^{35}$ New Jersey in 1969 amended its act by striking language which did not require "any employer of farm laborers" to carry compensation insurance. ${ }^{38}$ Illinois and Washington have also recently enacted legislation broadening the scope of coverage for the agricultural worker. ${ }^{37}$

The recent trend of the legislatures to extend workmen's compensation coverage to farm workers is reflected also in the recommendations of several important nation-wide studies. The Model Act of the Council of State Governments, for example, would require all agricultural employers to provide coverage, with the exception of those who have fewer than three employees. ${ }^{38}$ Recommended standards compiled by the United States Department of Labor, furthermore, would cover farm workers on essentially the same basis as other employees. ${ }^{30}$ Most recently, the National Commission on State Workmen's Compensation Laws recommended a two-stage approach to agricultural coverage. As a first stage, the Commission suggested that as of July 1 ,

vania, PA. Stat. ANN. tit. 77, § 1a (Purdon 1952); Rhode Island, R.I. GEN. Laws ANN. \$ 28-29-7 (1969); South Carolina, S.C. CODE ANN. \$\$ 72-13, 72-107 (1962); Tennessee, Tenn. Code Ann. $\$ 50-906$ (1966); Texas, Tex. Rev. Civ. Stat. Ann. art. 8306 (Vernon 1967); Utah, UTAH CODE ANN. \$ 35-1-43 (1966); Virginia, VA. CODE ANN. \$ 65.1-28 (1973); West Virginia, W. VA. CODE ANN. \& 23-2-1 (1970).

35. MD. ANN. CODE art. 101, $\S 21$ (Supp. 1972). It should be noted, however, that the recent Maryland amendment defined "farmer" as "one who has three (3) or more full-time employees or who has a yearly payroll for his full-time employees of at least fifteen thousand dollars $(\$ 15,000)$, provided, however, that this seetion shall not apply to seasonal or migratory farm laborers who do not operate machinery or equipment." Id.

36. N.J. REv. STAT. $\$ \S 34: 15-36,34: 15-92$ (Supp. 1972).

37. Illmois, through legislation effective in 1971, removed large-scale farming operations froin its prior complete exclusion of "work . . . condueted by farmers." Ill. ANN. Stat. ch. 48, $\$ 138.3$ (Snrith-Hurd Supp. 1972). Washington in 1971 amended its prior list of einployments included within the act, which had omitted agricultural employment, to presently "embrace all employments which are within the legislative jurisdiction of the state." WASH. REv. CODE \$ 51.12.020 (Supp. 1972). It should be noted, however, that Illinois chose to continue its exclusion for the small farmer and for the employer of exchange labor, and that Washington chose to exclude seasonal workers and those employees earning less than $\$ 150$ a calendar year from any one employer.

38. Council of State Governments, Workmen's Compensation and RehabiliTATION LAW 20, reprinted from SUgGested STATE LEgislation (1963 \& 1965).

39. U.S. Bureau of Labor Standards, Dep't of Labor, Bull. No. 212, State Workmen's COMPensation LaWs: A COMparison of Major Provisions with RecOMMENDED STANDARDS 6 (1967 revision). 
1973, each agricultural employer with an annual payroll in excess of $\$ 1,000$ be required to provide full workmen's compensation coverage to all of his employees. As a second stage, all farm workers would be covered on the same basis as all other employees as of July 1, 1975, without regard to limitations on employer payroll size. ${ }^{40}$

\section{Constitutionality of the Agricultural Exclusion IN WORKMEN'S COMPENSATION STATUTES}

In contrast to the recent proposals arising out of these national studies must be placed the recalcitrant attitude of many state legislatures whose rural representatives and lobbyists are firmly opposed to reform in the area of the workmen's compensation coverage of agricultural enployees. ${ }^{41}$ Thus, proponents of coverage for farm workers have at times turned to the courts for assistance, basing their objections primarily on the argument that the agricultural exclusion denies equal protection of the law in violation of state constitutions or the fourteenth amendment of the United States Constitution.

\section{General Equal Protection Standards}

Two different tests of equal protection analysis have been developed by the Supreme Court over the years. The first of these two tests has often been termed the "traditional" or "minimal scrutiny" equal protection test. Here, the weakest of reasons for differentiation between classes will suffice, for so long as the classification bears a rational relationship to a legitimate legislative purpose, it will be upheld. The classification is permissible, in other words, as long as there is any reasonable basis for its existence. ${ }^{42}$ The second of these two

40. Commission Report 46. The Commission recognized that the use of group insurance covering several employers may serve to ease any administrative burden involved in its recommended plan. $I d$.

41. See notes 15-16 supra and accompanying text.

42. See, e.g., San Antonio Independent School Dist. v. Rodriguez, 93 S. Ct. 1278, 1302-08 (1973); Shapiro v. Thompson, 394 U.S. 618, 638 (1969). Among those classifications held to bear a reasonable relationship to a proper legislative purpose are certain licensing statutes, Goesaert v. Cleary, 335 U.S. 464 (1948) (Michigan statute denying bartending licenses to all women except the wives or daughters of male bar owners had the conceivable legitimate legislative purpose of avoiding social and moral problems attendant to employment of women in bars), and prohibitions on advertising, Railway Express Agency v. New York, 336 U.S. 106 (1949) (New York City ordinance prohibiting motor carriers from hiring-out advertising space on their trucks while permitting firms owning trucks to advertise their own products was upheld, as those who hire out advertising space might present a greater danger of traffic distraction than those who advertise their own goods). For an excellent discussion of the "traditional" equal protection test, see Note, Developments in the Law-Equal Protection, 82 HARV. L. ReV. 1065, 1077-78 (1969). 
tests has been at times designated the "strict scrutiny" or "steppedup" test. Here, whenever a "fundamental interest" is affected or the basis of classification involves a "suspect criterion," a stepped-up standard of judicial review emerges, requiring that the classification serve a compelling state interest $\mathrm{m}$ order to be held constitutional. ${ }^{43}$

It is unlikely that the agricultural exclusion in workmen's coinpensation statutes is examinable under the "strict scrutiny" test, because such a classification neither impinges upon a fundamental interest nor is based upon a suspect criterion. In the first place, the Supreme Court has recently stated that only those rights "explicitly or implicitly protected by the Constitution" will be deemed "fundamental" for equal protection purposes, and that "social importance is not the critical determinant for subjecting state legislation to strict scrutiny." 44 On the basis of this general restriction imposed by the Court and analogous cases denying the status of "fundamental imterest" to an indigent's right to receive state welfare assistance, ${ }^{45}$ it seems highly un-

43. See Shapiro v. Thompson, 394 U.S. 618, 658 (1969). See also Developments in the Law, supra note 42, at 1087-1132. Among those classifications considered by the courts to be "suspect" and thus sufficient to invoke strict judicial scrutiny include: race, McLaughlin v. Florida, 379 U.S. 184 (1964), see note 48 infra; national ancestry, Korematsu v. United States, 323 U.S. 214 (1944); alienage, Sei Fujii v. State, 38 Cal. 2d 718, 242 P.2d 617 (1952); illegitimacy, Gomez v. Perez, 93 S. Ct. 872 (1973).

Wealth alone, on the other hand, has never been held by the Supreme Court to be a "suspect" classification. San Antonio Independent School Dist. v. Rodriguez, 93 S. Ct. 1278, 1294 (1973). Sce note 47 infra and accompanying text.

The term "fundamental interest," whose potential infringement in a statutory classification justifies use of the stepped-up standard of judicial review, has been defined by the Supreme Court recently to consist of only those rights which are "explicitly or implicitly protected by the Constitution." San Antonio Independent School Dist. v. Rodriguez, 93 S. Ct. 1278, 1288 (1973). "Fundamental interests," generally held sufficient to trigger the stepped-up standard of judicial review, include: voting, Reynolds v. Sims, 377 U.S. 533 (1964); procreation, Skinner v. Oklahoma ex rel. Williamson, 316 U.S. 535 (1942); procedural rights of criminals, Griffin v. Illinois, 351 U.S. 12 (1956); and interstate travel, Shapiro v. Thompson, 394 U.S. 618 (1969). Contrary to the implications suggested in Brown v. Board of Edueation, 347 U.S. 483 (1954), education is not a fundamental constitutional right, San Antonio Independent School Dist. v. Rodriguez, 93 S. Ct. 1278, 1299 (1973); nor, for example, is the right to housing, Ludsey v. Normet, 405 U.S. 56 (1972).

44. San Antonio Independent School Dist. v. Rodriguez, 93 S. Ct. 1278, 1288, 1296 (1973).

45. In Dandridge v. Williams, 397 U.S. 471 (1970), for example, the Supreme Court held that a Maryland statute denying additional welfare benefits per child to a family once it reached a maximum size did not impinge on any fundamental interests and therefore would not be examined under the "stepped-up" standard of equal protection analysis. Workmen's compensation benefits are likely to fall within the same category as welfare benefits, for it would appear that compensation benefits, like pub- 
likely that the right to receive workmen's compensation coverage would be accorded the status of a "fundamental" interest. ${ }^{48}$ The only alternative basis for applying strict judicial scrutiny to the agricultural exclusion in workmen's compensation statutes, then, would constitute making the assumptions that (1) most farm workers are poor, and hence, the statutory classification parcels out compensation coverage on the basis of wealth, and (2) wealth is a "suspect criterion." However, the Supreme Court has never considered wealth alone to be a suspect basis of classification, and has exhibited no present indications of an intent to do so. ${ }^{47}$ Should wealth be deemed "suspect," agricul-

lic welfare assistance, though involving "the most basic economic needs of impoverished human beings," present "intractable economic, social, and even philosophical problems ... [whicl]] are not the business of [the] Court." Id. at $485,487$.

46. In the Rodriguez case, the Supreine Court refused to recognize that the right to receive public education was a "fundamental right" protected by the Constitution. Consequently, the Court applied the traditional standard of equal protection analysis in upholding the Texas scheme of financing public education, which was based in part on the amount of property taxes collected in each school district. San Antonio Independent School Dist. v. Rodriguez, 93 S. Ct. 1278 (1973). In denying "fundamental" protected status to the riglit to receive education, the Court postulated that the list of fundamental rights would be limited to those rights explicitly or implicitly guaranteed by the Constitution, regardless of the social importance of other interests whicli are not constitutionally protected-interests such as the right to receive public scliool education and, in all probability, the right to be covered by a scheme of workmen's coinpensation benefits. Noting that "the importance of a service performed by the State does not determine whether it must be regarded as fundamental for purposes of examination under the Equal Protection Clause," 93 S. Ct. at 1295, the Supreme Court summarized:

It is not the province of this Court to create substantive constitutional rights in the name of guaranteeing equal protection of the laws. Thus the way to discovering whether education is "fundamental" is not to be found in comparisons of the relative societal significance of education as opposed to subsistence or lrousing. .... Rather, the answer lies in assessing whether there is a right to education explicitly or implicitly guaranteed by the Constitution. $93 \mathrm{~S}$. Ct. at 1297 (citations omitted).

47. See San Antonio Independent Scliool Dist. v. Rodriguez, 93 S. Ct. 1278 (1973).

The Supreme Court has found violations of equal protection in instances where wealth was the basis of classification; however, the decision in each case rested upon the presence of a "fundamental interest," not the nature of the classification per se. See Harper v. Virginia Bd. of Elections, 383 U.S. 663 (1966); Douglas v. Califorma, 372 U.S. 353 (1963); Griffin v. Illinois, 351 U.S. 12 (1956). But see McDonald v. Board of Election Comm'rs, 394 U.S. 802, 807 (1969), where the Court, in holding that rllinois' failure to provide absentee ballots for incarcerated electors awaiting trial did not violate the equal protection clause, mentioned that a "careful examination" was in order whenever lines are drawn on the basis of wealth.

In Rodriguez, however, the Court stated that "this Court has never heretofore held that wealth discrimination alone provides an adequate basis for invoking strict scrutiny," $93 \mathrm{~S}$. Ct. at 1294, the Court refused to apply the stepped-up standard of judicial review. The Court concluded: 
tural workers denied workmen's compensation benefits could conceivably demand stepped-up scrutiny of the exclusion, due to the disadvantaged, impoverished existence experienced by many farm workers, especially migrants. ${ }^{48}$ In the meantime, however, the courts undoubtedly will continue to refuse to apply the "stepped-up" standard of equal protection analysis when examining the alleged unconstitutionality of classifications in social legislation, such as workmen's compensation schemes, which do not impinge upon any constitutionally guaranteed "fundamental" rights. ${ }^{49}$

The argument here is not that the children in districts having relatively low assessable property values are receiving no public education; rather, it is that they are receiving a poorer quality education than that available to children in districts having more assessable wealth. ... [A] sufficient answer to appellee's argument is that at least where wealth is involved the Equal Protection Clause does not require absolute equality or precisely cqual advantages. $93 \mathrm{~S} . \mathrm{Ct}$. at 1291.

See Jefferson v. Hackney, 406 U.S. 535, 546-47 (1972), where the Court stated: "So long as its judgments are rational, and not invidious, the legislature's efforts to tackle the problems of the poor and the needy are not subject to a constitutional strait jacket. The very complexity of the probleuns suggests that there will be more than one constitutionally permissible unethod of solving them" (emphasis added). See also James v. Valtierra, 402 U.S. 137 (1971) where the Court, in ruling that a California procedure barring public low income housing projects without the approval of a majority vote in a referendum did not violate equal protection, made no mention whatsoever of wealth as a suspect classification.

48. Race is the archetype of suspect bases of classification. The Supreme Court has never offered a full explanation for the treatment of race as suspect, even though the Court has never deviated from its 1941 statement in Korematsu v. United States, 323 U.S. 214, 216, that "all legal restrictions which curtail the civil rights of a single racial group are immediately suspect" and should be subjected "to the most rigid scrutiny." For a recent reaffirmation of this expression, see Loving v. Virginia, 388 U.S. 1 (1967).

Policies underlying the suspect treatment of race would appear to include efforts to protect the minority-like characteristics associated with many racial groups, and atteinpts to recognize that race is a trait "over which an individual has no control and for which he should receive neither blame nor reward." See Developments in the Law, supra note 42, at 1124-27. Utilization of such classifications is not likely to be related to the furtherance of a legitimate state interest. Wealth arguably exhibits these same characteristics when low income segments of the populaion are at issue, for distinctions based on wealth likewise tend to point out the disadvantaged, stigmatic characteristics of the "have-nots" of society, and similarly unrelated to furthering any legitimate state interest. See Michelman, On Protecting the Poor Through the Fourteenth Amendment, 83 HARV. L. REv. 7, 21 (1969). As the agricultural exclusion involves distinctions based on wealth, it arguably triggers the necessity for a compelling state interest to be served by such ordinances. See notes 70-72 infra and accoinpanying text. The courts, however, have generally refused to go so far as to apply stepped-up review to classifications based on wealth. See note 47 supra and accompanying text. For background evidence linking the agricultural worker to classifications based on wealth, see note 10 supra and accompanying text.

49. It is worthy of note that the Supreme Court of Michigan in Gallegos v. Glaser Crandell Co., 388 Mich. 654, 202 N.W.2d 786 (1972), the first, and heretofore 
Recently, there have been indications that the Court is developing a new equal protection standard which would replace the "traditional" test with a inore intensive judicial scrutiny of statutory classifications and which, at the same time, would impair the stepped-up test of "strict scrutiny." "50 Under this new standard, the constitutionality of a statute will no longer be satisfied when a court perceives that a classification has a rational relationship to any legislative purpose which the court envisions to be "legitimate." Rather, the statutory "means" of classification, in order to comply with the new equal protection standard, must have a substantial relationship to the legislative purposes actually chosen by the state legislatures. ${ }^{51}$ Furthermore, the previously devel-

only, direct judicial examination of the constitutional validity of the agricultural exclusion of workmen's compensation statutes, applied the "traditional" test of equal protection analysis, rather than the stepped-up standard of judicial review. See notes 67-76 infra and accompanying text.

50. See Gunther, The Supreme Court, 1971 Term-Foreword: In Search of Evolving Doctrine on a Changing Court: A Model for a Newer Equal Protection, 86 HARv. L. REv. 1, 17-24 (1972). The author postulates, on the basis of recent Supreme Court decisions, that the Court las replaced the "traditional" standard of equal protection with a significantly more stringent test, called an "intensified means scrutiny." The commentator observes that statutory classifications with only a minimum of rationality will not necessarily pass equal protection muster under the new test. Rather, the Court, using this new standard, "is prepared to acknowledge substantial equal protection claims on minimum rationality grounds." Id. at 19. In comparing the new test with the old, the commentator notes:

The intensified means scrutiny would, in slort, close the wide gap between the strict scrutiny of the new equal protection and the minimal scrutiny of the old not by abandoning the strict but by raising the level of the minimal from virtual abdication to genuine judicial inquiry. Id. at 24 .

This new development in equal protection analysis has been judicially recognized, at least in the Second Circuit. See, e.g., City of New York v. Richardson, 473 F.2d 923 (2d Cir. 1973); Aguayo v. City of New York, 473 F.2d 1090 (2d Cir. 1973). In referring to the analysis in Gunther, supra, and recent Supreme Court decisions, the Second Circuit stated in the Richardson case:

Clearly, these decisions seein to foreshadow an expanded judicial inquiry under the Equal Protection Clause, although the outer boundary of that inquiry remains ambiguous. Id. at 931 .

51. One commentator has recently explaimed the workings of this new standard as follows:

Stated most simply, [the new test] would lave the Court take seriously a constitutional requirement that has never been formally abandoned: that legislative means must substantially further legislative ends. The equal protection requirement that legislative classifications must liave a substantial relationship to legislative purposes is, after all, essentially a more specific formulation of that general principle. ... [The new test] would liave the Court assess the means in terms of legislative purposes that liave substantial basis in actuality, not merely in conjecture. Moreover, it would liave the justices gauge the reasonableness of questiouable means on the basis of materials that are offered to the Court, rather than resorting to rationalizations created by perfunctory judicial hypothesizing. . . The yardstick for the acceptability of the means would be the purposes chosen by the legislatures, not "constitutional" interests drawn from the value perceptions of the Justices. Gunther, supra note 50, at 20-21. 
oped stepped-up standard will not be abandoned, since the presence of fundamental interests or suspect classifications will dictate that the means of classification inust be "necessary" and able to withstand "strict scrutiny." 52

\section{Traditional Failure of Equal Protection Attacks on Workmen's Com- pensation Statutes}

Few parties have mounted successful equal protection attacks against the various classifications or exclusions in workmen's compensation statutes, ${ }^{53}$ and, in particular, none of the early attacks on the agricultural exclusion has succeeded. A noted illustrative case is New York Central Railroad $v$. White, ${ }^{54}$ in which a wife was awarded compensation for the death of her husband who was killed while in the employ of defendant railroad company. In argument before the Supreme Court, the railroad company challenged the act as denying the railroad equal protection of the law since the act excluded agricultural and domestic workers but required railroad employers to maintain coverage for its employees. The Court, in applying the "traditional" equal protection analysis, rejected defendant's argument, stating:

But, manifestly, this cannot be judicially declared to be an arbitrary classification, since it reasonably may be considered that the risks inherent in these occupations [agricultural and domestic work] are exceptionally patent, simple, and familiar. ${ }^{55}$

The absence until recently of case law dealing with the constitutionality of the agricultural exclusion indicates that proponents of cov-

52. See note 43 supra.

53. See, e.g., Lower Vein Coal Co. v. Industrial Bd., 255 U.S. 144 (1921) (workmen's compensation law, mandatory as to coal-mining companies, but permissive as to all other corporations, does not deny equal protection of the laws). Johnston v. Kennecott Copper Corp., 248 F. 407 (9th Cir. 1918) (Alaska compensation act applying only to mining industry held not violative of equal protection); Ives v. Snrith Buffalo Ry., 201 N.Y. 271, 94 N.E. 431 (1911) (workmen's compensation act imposing absolute liability on employers for injuries to employees engaged in specified dangerous activities did not violate equal protection).

54. 243 U.S. 188 (1917).

55. Id. at 208. See also Middleton v. Texas Power \& Light Co., 249 U.S. 152 (1919) (exclusion of farm laborers does not render a state compensation statute unconstitutional as class legislation nor as violative of the equal protection clause); Roush v. Hefflebower, 225 Mich. 664, 196 N.W. 185 (1923) (statement in dicta that the power to except farm laborers is based on the fact that there is a reasonable and substantial distinction between conditions under which farm labor is performed and conditions under which work in other employments is done); Mackin v. DetroitTimken Axle Co., 187 Mich. 8, 153 N.W. 49 (1915) (it is within the power of the legislature to classify both employers and employees, if the classification is not fanciful or arbitrary and applies impartially and equally to each member of the class). 
erage for farm workers soon abandoned their constitutional attacks on the agricultural exclusion after these early judicial setbacks. A notable exception, although not dealing specifically with the agricultural exclusion, is the 1960 decision by the Supreme Court of Michigan in Gauthier v. Campbell, Wyatt \& Cannon Foundary Co. ${ }^{56}$ Gauthier involved an attempt to have the special statutory limits on silicosis benefits struck down as a violation of equal protection. Claimants argued that a statute which might have been constitutional when passed could become unconstitutional by the disappearance of the conditions which had sustained the constitutionality of the original enactment. The court rejected the argument, holding that at the time the claimants' rights accrued the classification was not obsolete. However, the court did not rule out the possibility of reconsidering the claimants' argument in a future case when there was stronger evidence of obsolescence:

Any argument that the scheme is now "obsolete" as to future disabilities must wait consideration on a record which presents some facts from which it might be deduced that the legislative reasoning had lost all value with the passage of time and change of circumstances..$^{57}$

\section{The Gallegos Decision}

An ideal case for unconstitutionality due to the obsolescence of a statutory classification, found not to be present in the Gauthier decision, presented itself finally in Gallegos v. Glaser Crandell Co. ${ }^{58}$ as applied to a different statutory scheine-the agricultural exclusion of workmen's compensation. Choosing not to adopt the constitutional obsolescence doctrine, however, and applying, instead, the "traditional" test of equal protection analysis, the Supreme Court of Michigan held in Gallegos that Michigan's separate compensation treatment for agricultural employees had violated the equal protection clauses of the federal and state constitutions. As a result of this decision, the Michigan court may have started a reversal of the earlier judicial trend which did not regard the agricultural exclusion as violative of the farm laborer's equal protection of the laws.

In Gallegos, plaintiffs were migrant workers employed to larvest cucumbers by defendant Glaser Crandell. Both plaintiffs were injured by falling from the same exterior stairway which led to living quarters supplied for thein by the defendant employer. The Michigan statute

56. 360 Mich. 510, 104 N.W.2d 182 (1960).

57. Id. at 523-24, 104 N.W.2d at 188-89. The court's reasoning appears to be in part an explication of the "traditional" equal protection test.

58. 388 Mich. 654, 202 N.W.2d 786 (1972), rev'g 34 Mich. App. 489, 192 N.W.2d 52 (1971). 
was of a hybrid variety, ${ }^{50}$ providing full coverage only for those agricultural employees who were paid an hourly wage or salary (and not on a piecework basis) and who worked thirty-five or more hours per week for thirteen or more consecutive weeks for the same employer, as long as the employer had at least three such regular employees within his hire. Furthermore, the statute provided medical and hospital coverage for only agricultural employees who worked thirty-five or more hours per week for five or more consecutive weeks for the same employer who had at least one such employee within his hire. ${ }^{00}$

After both the hearing referee and the Workmen's Compensation Appeal Board ruled that they lacked authority to decide constitutional issues, plaintiffs placed two arguments before the Michigan Court of Appeals attacking the constitutionality of the statute. First, plaintiffs argued that the act, by excluding piecework farm laborers from coverage while covering permanent salaried or wage-earning farm laborers, was unconstitutional as a restriction on the constitutional right to inter-

59. See note 30 supra and accompanying text.

60. Section 115 of the Michigan Workmen's Compensation Act of 1969, Mick.

Comp. LAwS $\& 418.115$ (1948), provides that the coverage of the act shall apply to:

(a) All private employers, other than agricultural employers, who regularly employ 3 or more employees at 1 time.

(b) All private employers, other than agricultural employers, who regularly employ less than 3 employees if at least 1 of them has been regularly employed by the same employer for 35 or more hours per week for 13 weeks or longer during the preceding 52 weeks.

(c) All public employers, irrespective of the number of persons employed. (d) All agricultural employers of 3 or more regular employees paid hourly wages or salaries, and not paid on a piecework basis, who are employed 35 or more hours per week by that same employer for 13 or more consecutive weeks during the preceding 52 weeks. Coverage shall apply only to such regularly employed employees. The average weekly wage for such an employee shall be deemed to be the weeks worked in agricutural employment divided into the total wages which the employee has earned from all agricultural occupations during the 12 calendar months immediately prcceding the injury, and no other definition pertaining to average weekly wage shall be applicable.

(e) All agricultural employers of 1 or more einployees who are employed 35 or more hours per week by that same employer for 5 or more consecutive weeks shall provide for such employees, in accordance with rules established by the director, medical and hospital coverage as set forth in section 315 for all personal injuries arising out of and in the course of employment suffered by such employees not otherwise covered by this act. The provision of such medical and hospital coverage shall not affect any rights of recovery that an employee would otherwise have against an agricultural employer and such right of recovery shall be subject to any defense the agricultural employer might otherwise have. Section 141 shall not apply to cases, other than medical and hospital coverages provided herein, arising under this subdivision nor shall it apply to actions brought against an agricultural employer who is not voluntarily or otherwise subject to this act. No person shall be considered an einployee of an agricultural einployer if the person is a spouse, child or other member of the employer's family, as defined in subdivision (b) of section 353 residing in the holne or on the premises of the agricultural employer.

(f) All other agricultural employers not included in subdivisions (d) and (e) shall be exempt from the provisions of this aet. 
state travel. ${ }^{61}$ In rejecting this argument, the court held that the act apphed to residents and nonresidents alike:

[I]t cannot be said that [the act] has 'no other purpose . . . than to chill the assertion of constitutional rights [in this instance the right to travel] by penalizing those who chose to exercise them . . . .62

Second, plaintiffs argued that the exclusion was unconstitutional as an arbitrary and unreasonable classification denying the equal protection of the laws guaranteed by the fourteenth amendment of the United States Constitution and the Michigan Constitution. ${ }^{63}$ The court disagreed, declaring that state legislatures presumptively act within constitutional boundaries despite the fact that, in practice, their laws result in some inequality, ${ }^{64}$ and that the legislature can choose to institute reforms by taking one step at a time. ${ }^{65}$ In rejecting plaintiffs' equal protection claim, the intermediate court was particularly impressed with legislative findings that indicated coverage for all agricultural workers would bear a prohibitive cost. ${ }^{66}$

Appealing to the Michigan Supreme Court, plaintiffs relied on the same bifurcated attack rejected by the Michigan Court of Appeals. In a decision producing four separate opinions, the unajority, by applying the "traditional" test of equal protection analysis, held that the different compensation treatment accorded farm workers in section 115 (d) of the act, as compared to the treatment given to other types of employees, did violate plaintiffs' rights to equal protection. The inajority, in noting the three classifications of employers created by section 115 -all private employers, all public employers, and all agricultural employers $^{67}$ - found the last classification to be unconstitutional.

Agricultural einployers, regardless of the skills of their einployees or the activities engaged $\mathrm{m}$, are accorded a special treatment and classification

61. Plaintiffs rehed heavily on Shapiro v. Thompson, 394 U.S. 618 (1969), in which the Supreme Court invalidated state welfare laws which set a one-year residence requirement to qualify a person for pnblic assistance. Such a requirement was thought to impair the fundamental constitutional right of a citizen to move from one state to another. Because the requirement was viewed as serving no compelling state interest, it was held in Shapiro to be violative of equal protection under the stepped-up standard of judicial review applied by the Court. See note 43 supra and accompanying text.

62. Gallegos v. Glaser Crandell Co., 34 Mich. App. 489, 493, 192 N.W.2d 52, 54 (1971), rev'd, 388 Mich. 654, 202 N.W.2d 786 (1972).

63. See Mich. Const. art. 1, \& 2 (1963).

64. 34 Mich. App. at 495-97, 192 N.W.2d at 55-56. The court quoted from McGowan v. Maryland, 366 U.S. 420 (1961). 34 Mich. App. at 496-97, 192 N.W.2d at 55-56.

65. The quotation from McGowan cited Sembler v. Oregon State Bd. of Dental Examiners, 294 U.S. 608 (1935).

66. 34 Mich. App. at 497, 192 N.W.2d at 56.

67. See note 60 supra and accompanying text. 
of their employees not accorded any other private or public employer. Such treatment is impermissible, clearly discriminatory and has no rational basis. ${ }^{68}$

The majority reasoned that there was no rational basis for singling out for different compensation treatment the work of a laborer on a farm from the similar activities performed by a laborer in industry, wholesaling, retailing, or building. Based on the court's rationale, therefore, it would appear that any workmen's compensation scheme which offers agricultural employees treatment significantly different from that accorded other employees in general will be unconstitutional. ${ }^{60}$

In a concurring opinion, Justice T.G. Kavanagh acknowledged the basic reasonableness of a broad classification of workers imto an agricultural class as opposed to other classes, such as "industrial workers," but considered the creation of two separate subclasses-agricultural workers covered by the act and those not covered-as unconstitutional. The concurring Justice stressed first that the excluded subclass (agricultural workers paid on a piecework basis or not employed at least thirty-five hours a week for at least twelve consecutive weeks for the same employer) consisted of "seasonal workers" and was largely composed of blacks, chicanos, and Indians. Noting that seasonal agricultural workers comprise one of the poorest segments of society, ${ }^{70}$ Justice Kavanagh then determined that the combination of this subclassification based on wealth coupled with "a possible fundamental interest as found in Shapiro"11 caused section 115 to trigger the "stepped-up" standard of judicial review for equal protection analysis. Finding that

68. 388 Mich. at 654,202 N.W.2d at 791 (emphasis added).

69. Id. at 667,202 N.W.2d at 804. The Gallegos Court indicated that any differential treatment accorded a worker merely because he was an agricultural employee would have no rational basis and would be unconstitutional:

There is no basis for distinguishing the work of a laborer who drives a truck at a factory from a laborer who drives one on the farm or for any one of numerous other labor activities "on the farm" as distinguished from the same activity in industry, wholesaling, retailing, or building. There is no basis for singling out for an exclusion piecework "on the farm" but not elsewhere. There is no basis for a special definition of "weekly wage" for farm labor as distinguished from any other type of labor. "All private employers" coine under the act if they regularly einploy 3 or more employees at one time. On the other hand, only "agricultural employers" who einploy 3 or more employees, not on piecework, 35 or more hours per week by the same employer for 13 or more weeks during the preceding 52 weeks come under the act. $I d$.

70. Justice T.G. Kavanagh was chided by the majority for taking judicial notice of these and other facts not in the record. Id. at 659-60,202 N.W.2d at 787.

71. $1 d$. at 673,202 N.W.2d at 794, citing Shapiro v. Thompson, 394 U.S. 618 (1969). Justice Kavanagh does not state what this "possible fundamental interest" is. Because plaintiffs presented it as a separate argument, the right to travel may not be the fundamental imterest referred to by Justice Kavanagh. See note 61 supra. 
no compelling state interest would justify the creation of this subclassification of seasonal agricultural workers, Justice Kavanagh would have held the statute unconstitutional on that basis. ${ }^{72}$ As support for its result, the concurring opinion emphasized the transformation of "farming" into an "agricultural industry," in which even the small farms that do exist cannot be distinguished from any other "small, family operated business." Furthermore, Justice Kavanagh stated that administrative and fimancial burdens resulting froin total coverage are highly unlikely, in light of withholding tax and social security already imposed on all farm employers, and in light of laws covering all agricultural workers in jurisdictions where numerous migrant workers are located. ${ }^{73}$

By applying the "traditional" test of equal protection to the agricultural exclusion, the majority in Gallegos properly recognized the irrationality of a separate classification for agricultural employees within a workmen's compensation scheme. In noting that there is no basis for distinguishing labor activity on the farm from labor activity in industry, nor for singling out piecework performed on a farm from other types of employment, the majority opinion acknowledges the dearth of justifications for the agricultural exclusion. ${ }^{74}$ Justice Kavanagh's concurring opinion, while perhaps of limited utility due to its apparent characterization of wealth as a "suspect criterion" and its resultant application

72. 388 Mich. at $674-75,202$ N.W.2d at 794. In another concurring opinion, Instice Williams, while siding with the majority in maintaining that facts in the record were not snfficient to establish a "suspect" classification based on wealth, agreed with Justice Kavanagh's view that the subclassification creating exceptions from the act was violative of equal protection. Justice Williams based his result, however, on the argument that the creation of a subclassification of "seasonal agricultural workers" was "altogether unreasonable and lacking in rational basis" and therefore unconstitutional even under the traditional test for equal protection analysis. Id. at 675-77, 202 N.W.2d at 795 . See note 42 supra and accompanying text.

In a dissent, Justice Breunan maintained that $\$ 115(\mathrm{e})$ did not discrininate against migrant farm workers; rather, the statute reflected a justifiable legislative decision to distinguish between large and sinall farms, and even provided migrant workers with a special remedy (medical and hospital coverage) unavailable to nonagricultural workers for small industrial employers. Id. at 677-79, 202 N.W.2d at 795-96.

73. Id. at 674, 202 N.W.2d at 794. Justice Kavanagh cited California and Ohio as jurisdictions with a high migrant worker population where all agricultural workers are covered by workmen's compensation. Id. at 674 n.12. See note 28 supra and accompanying text.

74. Under the new "intensified means scrutiny" approach to equal protection, the agricultural exclusion appears to be even more susceptible to attack. If, in light of the absence of justifications for the agricultural exclusion, the exclusion arguably has no rational nexus with a legitimate state interest, see notes 67-69 supra and accoinpanying text, it would be even more difficnlt to prove that the exclusion has a substantial relation with the legislature's purpose, within the meaning of the "new" equal protection test. See notes 50-52 supra and accompanying text. 
of the stepped-up standard of equal protection analysis, ${ }^{75}$ is valuable, however, for its implicit recognition of the doctrine of changing conditions and obsolescence of constitutional justifications which was previously rejected in Gauthier. ${ }^{76}$

\section{IMPLICATIONS OF Gallegos}

In recognizing the irrationality of excluding a particular group of agricultural laborers from compensation coverage, or of segregating the entire agricultural labor force for separate treatment, Gallegos may result in widespread ramifications both within and without the law of workmen's compensation. Certainly its rationale can be used as direct support for an attack on the total or partial exclusion of farm workers currently existing in forty state jurisdictions. ${ }^{77}$ Surprisingly enough, compensation coverage may in fact prove to be a boon to many unsuspecting farmers. As legal services become available to more farm workers, the farm employer may find himself subject to substantial personal injury verdicts. ${ }^{78}$ When compensation, coverage is undertaken by the farm employer, however, the risk of personal liability evaporates. ${ }^{79}$

It is also conceivable that Gallegos can be used to attack the statutory exemption of other particular categories of employees from workmen's compensation-notably domestic servants, who are excluded from coverage in forty-one states. ${ }^{80}$ Administrative burdens of record-keeping and correspondence have traditionally been the major justification for exclusion of domestics. ${ }^{81}$ The cold reception given by

75. See notes 70-73 supra and accompanying text.

76. See 388 Mich. at 674,202 N.W.2d at 794. See also notes 56-57 supra and accompanying text.

77. It would appear that the Gallegos rationale, which on its facts applied to a statute which made provisions for some agricultural employees, see note 60 supra and accompanying text, would command greater persuasiveness when applied to a statute totally excluding farm workers from its reach.

78. Employers not covered by compensation arguably are taking undue chances, as substantial jury awards have been made against them. In Pezzo v. Paterno, 302 N.Y. 884, 100 N.E.2d 176 (I95I), for example, a farmhand, who had suffered relatively minor imjuries when his trousers were caught in a tractor, received a $\$ 12,000$ jury award. See also Bull. No. 206, supra note 4, at 3.

79. Under the typical workmen's compensation act the employee and his dependents, in exchange for compensation benefits, relinquish their common law right to sue the employer for damages for injuries covered by the act. See 1 LARSON $\S 1.10$.

80. See 2 LARSON $\$ 50.10$.

81. Commission Report 46-47. As stated by the Commission:

By their numbers alone, employers of household workers create a formidable task of record-keeping and correspondence. A single household may employ a bevy of transient, part-time workers, such as gardeners or babysitters, during 
the concurring opinion of Justice Kavanagh in Gallegos to this justification as it applied to the agricultural exclusion might prove of assistance in striking down this major exclusion. ${ }^{82}$ Similar attacks on the exclusion of casual workers, employees of nonprofit, religious, charitable, or public institutions, and newsboys may also succeed in light of Gallegos. Despite the fact that each category possesses practical or historical factors supporting its exclusion from the act, all can arguably be depicted as "clearly discriminatory [with] no rational basis." $" 83$

Outside the area of workmen's compensation as well, the Gallegos rationale may provide ammunition to attack the exclusion of agricultural workers from federal and state social legislation. At the federal level, agricultural workers have always been excluded from the provisions of the National Labor Relation Act (NLRA), ${ }^{84}$ Thus, farm workers are denied federal protection in organizing into labor unions to bargain collectively and to engage in other concerted activities sanctioned by section 7 of the NLRA. ${ }^{85}$ In addition, agricultural employees are denied access to the National Labor Relations Board's adjudication of employer and union unfair labor practices. ${ }^{80}$

The legislative history of the NLRA evidences a total lack of concern for the problems of agricultural labor. ${ }^{87}$ While the real reason

a year. The number of new households and the constantly shifting location of households add to the difficulties of notification and auditing. $I d$.

82. It could be argued that farm work is inherently more dangerous than domestic work, and therefore more deserving of compensation beuefits. Thus, a court which chooses to emphasize the hazardous nature of farm employinent in striking down a compensation provision excluding farm workers from coverage might not apply the same reasoning to the domestic worker exclusion. However, the court might be dissuaded if evideuce of the staggering number of accidents which occur within the home was forcefully presented by advocates seeking abohtion of the dounestic worker exclusion. See, e.g., Nader, Home Unsafe Home, 89 Ladies' Home Journal 70 (Jan. 1972). Over 20 million injuries, 4 million of which are disabling, and approximately 30,000 deaths occur annually in American hoines. Id. at 72.

83. See 388 Mich. at 669,202 N.W.2d at 791.

84. 29 U.S.C. $\S \S 151-87$ (1970). The NLRA states: "When used in this Subchapter ... [t] the term 'employee' shall include any employee . . . but shall not include any individual employed as an agricultural laborer ...." Id. $\$ 152(3)$. Domestic servants are also excluded under the NLRA. Id. § 152(3).

85. Section 7 of the NLRA, entitled "Rights of Employees . . .," provides in part: "Employees shall have the right to self-organization, to form, join, or assist labor organizations, to bargain collectively through representatives of their own choosing, and to engage in other concerted activities for the purpose of collective bargaining or other mutual aid or protection . ..." Id. $\$ 157$.

86. $I d . \S 158$.

87. For an excellent review of the legislative history concerning the exclusion of farm laborers from the NLRA, see Morris, Agricultural Labor and National Labor Legislation, 54 CALIF. L. REv. 1939 (1966). 
for the exclusion lies in the fact that it was a concession on the part of supporters of the NLRA seeking support from congressmen representing rural districts, ${ }^{88}$ two other rationales were supplied in 1935 to justify the congressional approach. ${ }^{89}$ First, Congress was convinced that, due to the serene nature of agricultural labor relations in the 1930's, there was no need for application of the NLRA to agricultural employment. ${ }^{90}$ This belief was, of course, unfounded in light of the widespread agricultural labor strife following the depression. ${ }^{01}$ Second, supporters of the agricultural exclusion maintained that NLRA regulation would impose impossible financial burdens upon the farmer. ${ }^{22}$ There was some merit to this argument due to the weak bargaining position of many farm employers faced with perishable crops, bad weather, and unpredictable production, prices, and markets. ${ }^{93}$ Yet this rationale is considerably weakened in light of the successful organization of the food processing industry under the NLRA $^{04}$ and the organization of field workers under some state labor laws. ${ }^{95}$

The Fair Labor Standards Act (FLSA), ${ }^{96}$ designed to maintain a minimum standard of living for all industrial workers engaged in commerce, was amended in 1966 to include farm workers. However, the Act contains limitations which effectively exclude the majority of agricultural workers. The chief exclusion is a 500 man-day limita-

88. Id. at 1954-55.

89. Id. at 1968.

90. See Hearings on S.1550 Before the Senate Comm. on Educ. and Labor, 76th Cong., 1st Sess., at 3638-39 (1939).

91. For a compilation of American agricultural strikes in the period 1930-39,

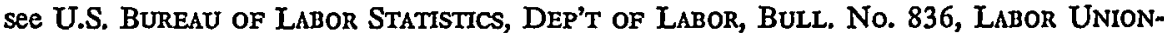
ISM IN AMERICAN AgRICULTURe 17 (1945).

92. See Hearings on S.1550, supra note 90, at 3580-84.

93. Agricultural Labor and National Labor Legislation, supra note 87, at 1971.

94. See NLRB v. Tepper, 297 F.2d 280, 282 (10th Cir. 1961), enforcing 129 N.L.R.B. 966 (1960).

95. Hawaii and Wisconsin have enacted labor laws protecting farm workers in organizational and bargaining activities. See Note, The Farm Worker: His Need for Legislation, supra note 10, at 236-37.

Of course, should the agricultural exclusion under the NLRA be successfully attacked under the Gallegos rationale, the jurisdietional standards of the National Labor Relations Board would work to exclude the employees of small farms since the Board, with reference to other operations, currently asserts jurisdiction over only those nonretail operations having an annual outflow or inflow across state lines of at least $\$ 50,000$. See Siemons Mailing Serv., 122 N.L.R.B. 81 (1958). It is conceivable that the Board could designate a lower standard applicable only to agriculture, should farm workers be included within the Act. See Note, The Farm Worker: His Need for Legislation, supra at 221-22.

96. 29 U.S.C. $\& 201$ et seq. (1970). The FLSA is best known for its minimum wage provisions. 
tion $^{97}$ which denies coverage to workers on farms enuploying less than 500 nuan-days of agricultural labor during any calendar quarter of the preceding year. ${ }^{98}$ Since the 500 man-day rule exudes the same arbitrariness as the Michigan piecework classification, Gallegos could be used to extend the coverage of the FLSA to all agricultural laborers. Similar effort could be directed towards the Social Security Act, ${ }^{99}$ which limits its coverage to farm workers who are paid nuore than $\$ 150$ in a calendar year or who work for an employer twenty days or more when paid on a time basis. ${ }^{100}$

State legislation discriminating against the farm laborer could also be subject to the Gallegos rationale. Unemployment insurance and minimum wage laws are two principal potential targets at the state level. At the present time, Hawain is the only state which includes farm laborers $\dot{m}$ its unemployment compensation laws. ${ }^{101}$ Again, the major justification given by the other states for exclusion lies in a belief that agriculture presents insurmountable administrative and financial costs for a program of unemployinent imsurance. ${ }^{102}$ Only seven states provide for a minimum wage for farm workers, and even these seven jurisdictions either limit the number of workers covered or deny to the farm worker the sanie minimum wage given to industrial employees. ${ }^{103}$

\section{CoNCLUSION}

Gallegos v. Glaser Crandell Co. adds a new dimension to the struggle of the agricultural employee to better his lot. Its equal protection analysis should provide a viable foundation for an attack on workmen's compensation statutes which discriminate against the farm

97. Id. at $\S 213(\mathrm{a})(6)$. The 500 man-day limitation applies only to agricultural employees.

98. A farmer employing about six workers during a full calendar quarter would not use 500 man-days of agricultural labor. S. Rep. No. 91-83, 91st Cong., 1st Sess. 56 (1969). For a discussion of the FLSA as applied to agricultural workers, see Note, The Farm Worker: His Need for Legislation, supra note 10, at 223-26.

99. 42 U.S.C. $\$ 401$ et seq. (1970).

100. Id. at $\$ 409(1)(2)$. This limitation applies only to agricultural employees.

101. See Hawait Rev. Stat. §§ 383-1(8), 383-2 (1968).

102. See Subcomm. on Migratory Labor of the Senate Comm. on Labor and Public Welfare, The Migratory farm labor Problem in the Untred States, S. REP. No. 1006, 90th Cong., 2d Sess. 2 (1968).

103. These seven states are Arkansas, ARK. STAT. ANN. \$ 81-320(g)(6)-(10) (Supp. 1971); Hawaii, HawaIr Rev. Laws $\$ 387-1(2)$ (1968); Massachusetts, Mass. ANN. Laws ch. 151, \& 2 (1965); Michigan, Mich. Comp. Laws \& 408.394 (1967); New Jersey, N.J. Stat. ANN. § 34:11-34 (1965); New Mexico, N.M. StaT. ANN. \$§ 59-3-21 (d), 59-3-22 (1953); and Oregon, Ore. Rev. Stat. \$ 653.020(1) (1971). See Note, The Farm Worker: His Need for Legislation, supra note 10, at 231-32. 
worker, and the migrant worker in particular. The Michigan Supreme Court wisely recognized in Gallegos that farming is no longer a simple family affair existing in a bucolic setting of lakes and green hills. Rather, farming today, even on a small scale, is a modern mechanized industry replete with incalculable possibilities of injury to those who work within it. A workmen's compensation system which ignores these realities and cliooses instead to require agricultural laborers, unlike industrial workers, to fend for themselves when injured in workrelated accidents is untenable in modern society and, according to Gallegos, violates the equal protection clause. Furthermore, the Gallegos rationale seems to provide a basis for attacking provisions of social legislation without as well as within the workmen's compensation area which arbitrarily discriminate against the agricultural employee. 